\title{
KEABSAHAN AKTA JUAL BELI TANAH YANG PERPAJAKANNYA BELUM TERBAYAR
}

\author{
Moh Ikang Fauzi \\ Magister Kenotariatan, Fakultas Hukum, Universitas Narotama Surabaya \\ Email : ikangfauzi.jurnal2018@gmail.com
}

\begin{abstract}
Transition of rights toward land and property can be occurred because of legal action and event. An example of legal action which stimulates rights transition of land coupled with property is sale and purchase. Rights transition need to be approved by authentic deed which is published by authorized legal officer (PPAT). Rights transition of land coupled with property through sale and purchase stimulate an occurrence of tax obligation for all parties which is known as Tax Income (PPh) for seller and custom of land and property rights for buyer (BPHTB).

The writing of this study wants to examine and analyze further about the legal standing of the land sale and purchase deed whose tax on the transfer of rights has not been paid and the legal impact borne by the parties to the land sale and purchase tax

The research method used is normative legal research, namely legal research conducted by examining library materials or secondary legal material while in searching for and collecting data is done with two approaches, namely the legal approach and the conceptual approach.

The results of the study indicate that the sale and purchase deed that has been made by PPAT is valid even though the tax arising from the transfer of rights to the land and the building has not been paid. The parties that do not pay taxes arising from the transfer of rights to land and buildings have debts to the state and may be subject to administrative sanctions in accordance with the provisions of the applicable legislation.
\end{abstract}

Keywords: Authentic Deeds, Sale And Purchase, Tax

\begin{abstract}
ABSTRAK
Peralihan hak atas tanah dan bangunan dapat terjadi karena suatu perbuatan hukum atau peristiwa hukum. Salah satu perbuatan hukum yang dapat membuat terjadinya peralihan hak atas tanah dan bangunan adalah melalui jual beli. Adanya peralihan hak tersebut harus dibuktikan dengan suatu akta otentik yang dibuat oleh atau dihadapan Pejabat Pembuat Akta Tanah (PPAT). Peralihan hak atas tanah dan bangunan melalui jual beli tersebut melahirkan kewajiban perpajakan bagi para pihak yaitu Pajak Penghasilan ( $\mathrm{PPh}$ ) bagi penjual dan Bea Perolehan Hak Atas Tanah Dan Bangunan (BPHTB) bagi pembeli.

Penulis dalam tesis ini ingin menelaah dan menganalisa lebih lanjut tentang kedudukan hukum akta jual beli tanah yang pajak atas peralihan haknya belum terbayar dan dampak hukum yang ditanggung oleh para pihak terhadap pajak jual beli tanah

Metode penelitian yang digunakan adalah penelitian hukum normatif, yaitu penelitian hukum yang dilakukan dengan cara meneliti bahan pustaka atau bahan
\end{abstract}


hukum sekunder sedangkan dalam mencari dan mengumpulkan data dilakukan dengan dua pendekatan, yaitu pendekatan Undang-Undang dan pendekatan konseptual.

Hasil penelitian menunjukkan bahwa akta jual beli yang sudah di buat oleh PPAT adalah sah meskipun pajak yang timbul dari peralihan hak atas tanah dan bangunannya belum dibayarkan. Para pihak yang tidak membayar pajak yang timbul dari peralihan hak atas tanah dan bangunan memiliki hutang kepada negara dan dapat dikenakan sanksi administrasi sesuai dengan ketentuan PerUndang-Undangan yang berlaku.

Kata Kunci : Akta Otentik, Jual beli, Pajak

\section{LATAR BELAKANG}

Keberadaan tanah bagi manusia memiliki fungsi yang sangat penting dalam kehidupan sehariharinya karena tanah itu sendiri merupakan salah satu sumber dari kehidupan manusia. Seluruh kegiatan manusia tentunya akan sangat bergantung pada tanah untuk melangsungkan kehidupannya seperti bercocok tanam, mendirikan rumah, bangunanbangunan berupa hotel, gedunggedung perkantoran, sarana transprotasi dan banyak lagi kegiatan manusia yang sangat membutuhkan keberadaan tanah.

Penggunaan hak atas tanah tersebut yang menghasilkan nilai ekonomis, tentunya mengharuskan rakyat untuk memenuhi kewajibannya untuk membayar iuran wajib kepada negara. Kewajiban untuk membayar iuran ini didasarkan atas tanah yang dikuasai oleh negara telah dipergunakan untuk kemakmuran rakyat Indonesia. Iuran wajib kepada negara yang sifatnya memaksa dan nantinya akan diperuntukkan untuk pembangunan negara dan pengeluaranpengeluaran negara tersebut selanjutnya disebut dengan pajak. wajib untuk dibayarkan kepada negara karena rakyat sendiri sudah memfungsikan tanah yang dikuasai oleh negara tersebut untuk kebutuhan hidupnya. Pemungutan pajak yang dilakukan oleh negara tidak hanya bertujuan untuk membiayai pengeluaran pengeluaran negara saja. Iuran wajib kepada negara yang sifatnya memaksa dan nantinya akan diperuntukan untuk pembangunan negara dan pengeluaranpengeluaran negara tersebut selanjutnya disebut dengan pajak.

Menurut P.J.A. Adriani : "Pajak merupakan iuran kepada negara yang dapat dipaksakan, yang terhutang oleh yang wajib membayarnya menurut peraturanperaturan dengan tidak mendapat prestasi kembali, yang langsung dapat ditunjuk, dan yang gunanya untuk membiayai pengeluaranpengeluaran, pengeluaran umum berhubungan dengan tugas negara untuk menyelenggarakan pemerintahan. ${ }^{1}$ Dari pengertian tersebut dapat dilihat bahwa pajak merupakan sebuah iuran warga negara kepada negaranya sendiri, dalam hal mana iuran yang bersifat wajib dan/atau memaksa ini bukan merupakan sebuah kontraprestasi.

Pemungutan pajak yang dilakukan oleh negara tidak hanya bertujuan untuk membiayai pengeluaran pengeluaran negara saja. Terdapat dua fungsi dari dilakukannya pemungutan pajak oleh Negara. Pertama, fungsi Budgetair yang artinya pajak merupakan salah satu sumber penerimaan pemerintah untuk membiayai

1 P.J.A.Adriani, Pengantar Ilmu Hukum

Pajak, Cet. 3, Eresco, Bandung, 1987, hal. 2 
pengeluaran baik rutin maupun pembangunan, sebagai sumber keuangan negara. Upaya tersebut ditempuh dengan cara ekstensifikasi maupun intensifikasi pemungutan pajak melalui penyempurnaan peraturan berbagai jenis pajak seperti Pajak Penghasilan, Pajak Pertambahan Nilai, dan Pajak Penjualan atas Barang Mewah, Pajak Bumi dan Bangunan, dan lainlain. Kedua, fungsi Regulerend atau mengatur yang artinya pajak sebagai alat untuk mengatur atau melaksanakan kebijakan pemerintah dalam bidang sosial dan ekonomi, dan mencapai tujuantujuan tertentu diluar bidang keuangan.

Terjadinya peralihan hak atas tanah karena adanya transaksi jual beli menjadi salah satu dasar bagi negara dalam memungut pajak. Jual beli tersebut mengakibatkan adanya peralihan hak kepemilikan atas tanah, sehingga harus dengan menggunakan akta otentik yang dibuat oleh dan dihadapan Pejabat yang berwenang, dalam hal ini adalah Pejabat Pembuat Akta Tanah (PPAT) sebagai bukti bahwa telah terjadi suatu perbuatan hukum tertentu di bidang pertanahan.

Secara umum dalam terjadinya proses jual beli diawali dari suatu perjanjian. Perjanjian adalah perbuatan dimana satu orang atau lebih mengikat diri terhadap satu orang lain atau lebih menurut Doktrin pengertian perjanjian adalah suatu persetujuan dengan mana dua orang atau lebih saling mengikatkan diri untuk melaksanakan suatu hal dalam lapangan hukum kekayaan.

Setiap terjadinya peralihan hak melahirkan kewajiban perpajakan bagi pihak yang terlibat di dalamnya. Bagi pihak penjual akan dikenakan Pajak Penghasilan (PPh) yang bersifat final sebesar 2,5\% dan bagi pihak pembeli akan dikenakan Bea Perolehan Hak Atas Tanah Dan Bangunan (BPHTB) sebesar 5\% dari Nilai Perolehan Objek Pajak
Kena Pajak. Penentuan Nilai Perolehan Objek Pajak Kena Pajak dapat diketahui melalui rumusan Nilai Perolehan Objek Pajak dikurangi dengan Nilai Perolehan Objek Pajak Tidak Kena Pajak. Kewajiban perpajakan tersebut pada prinsipnya harus dilunasi sebelum ditandatanganinya akta jual beli dihadapan PPAT, baik itu $\mathrm{PPh}$ maupun BPHTB

\section{RUMUSAN MASALAH}

1) Bagaimana keabsahan Akta Jual Beli Tanah Yang Pajak PPH/BPHTB Belum Terbayar?

2) Apa Akibat Hukum Bagi Para Pihak Atas Pajak Jual Beli Tanah Yang Belum Terbayar?

\section{METODE PENELITIAN}

Metode yang digunakan dalam penelitian ini adalah metode penelitian yuridis normatif yang menekankan pada normanorma hukum dengan menganalisa Peraturan Perundang-Undangan terkait. Dalam Penelitian ini peneliti menggunakan dua metode pendekatan masalah yaitu :

a. Statute Approach, yaitu pendekatan dengan menelaah semua Peraturan PerUndang-Undangan yang bersangkut paut dengan permasalahan (isu hukum) yang sedang dihadapi.

b. Conseptual Approach, yaitu pendekatan yang beranjak dari pandanganpandangan dan doktrindoktrin yang berkembang di dalam ilmu hukum.

\section{PEMBAHASAN}

Keabsahan Akta Jual Beli Tanah Yang Pajak PPH/BPHTB Belum Terbayar

Jual beli merupakan salah satu diantara banyaknya perbuatan hukum 
yang dilakukan oleh manusia. Jual beli adalah termasuk perbuatan hukum dua pihak artinya yaitu perbuatan hukum yang dilakukan oleh dua pihak dan menimbulkan hakhak dan kewajibankewajiban bagi kedua pihak (timbal balik). Para pihak dalam perbuatan jual beli adalah pihak penjual dan pihak pembeli.

Menurut Soejono Soekamto, jual beli adalah perbuatan hukum memindahkan hak atas tanah yang bersifat terang dan tunai, terang berarti bahwa perbuatan hak tersebut harus dilakukan di kepala adat yang berperan sebagai pejabat. Yang menanggung keteraturan dan sahnya perbuatan pemindahan hak tersebut. ${ }^{2}$

Pasal $1457 \quad$ KUHPerdata memberikan pengertian tentang jual beli. Jualbeli adalah suatu perjanjian dengan mana pihak yang satu mengikatkan dirinya untuk menyerahkan suatu kebendaan, dan pihak yang lain untuk membayar harga yang telah dijanjikan.

Menurut UUPA, jual beli adalah proses yang dapat menjadi bukti adanya peralihan hak dari penjual kepada pembeli. Prinsip dasarnya adalah Terang dan Tunai, yakni dilakukan di hadapan pejabat umum yang berwenang dan dibayarkan secara tunai. Ini artinya jika harga yang dibayarkan tidak lunas maka proses jual beli belum dapat dilakukan.

Jual beli yang menyebabkan terjadinya peralihan hak harus dibuktikan dengan alat bukti tertulis berupa akta otentik. Akta adalah surat yang dibuat demikian oleh atau dihadapan pegawai yang berwenang untuk membuatnya menjadi bukti yang cukup bagi kedua belah pihak dan ahli warisnya maupun berkaitan dengan pihak lainnya sebagai hubungan hukum.

2 Soejono Soekamto, Hukum Adat

Indonesia, Raja Grapindo Persada, Jakarta, 2007,hHal. 120
Tentang segala hal yang disebut didalam surat itu sebagai pemberitahu hubungan langsung dengan perihal pada akta. ${ }^{3}$

Perolehan atau peralihan hak atas tanah yang terjadi karena jual beli, tukar menukar, hibah, pemasukan kedalam perusahaan (inbreng), pembagian hak bersama, pemberian hak guna bangunan / hak pakai atas tanah hak millik, pemberian hak tangungan, kuasa membebankan tak tangungan harus dilakukan dihadapan Pejabat Umum yang berwenang. Pejabat umum yang berwenang, dalam hal ini adalah Pejabat Pembuat Akta Tanah (PPAT), yang diangkat oleh kepala Badan Pertanahan Nasional RI. Kewenangannya untuk membuat aktaakta mengenai suatu perbuatan hukum tertentu yang berkaitan dengan pertanahan seperti yang telah disebutkan diatas.

Sebelum melakukan proses jual beli, penjual maupun pembeli harus memastikan bahwa tanah tersebut tidak sedang dalam sengketa atau tanggungan di Bank. Jika tanah tersebut sedang dalam permasalahan maka PPAT dapat menolak pembuatan Akta Jual Beli yang diajukan.

Esensi dari perjanjian jual beli dalam Pasal 1457 KUHPerdata adalah perjanjian dengan mana pihak yang satu mengikatkan dirinya untuk menyerahkan suatu kebendaan, dan pihak yang lain untuk membayar harga yang telah dijanjikan". Artinya bahwa para pihak sepakat untuk mengikatkan diri melakukan perbuatan hukum yaitu pihak penjual menyerahkan barang yang dijual dan pihak pembeli mendapatkan barang dengan akan membayarkan sejumlah uang yang telah disepakati harga barang tersebut.

Dalam terjadinya proses jual beli adanya suatu perjanjian jual beli,

3C.S.T. Kansil, Pengantar Hukum Perdata, Rineka Cipta, Jakarta, 2012, hal. 50 
terjadinya perjanjian jual beli diatur pada Pasal 1313 KUHPerdata perjanjian yaitu perbuatan dimana satu orang atau lebih mengikat diri terhadap satu orang lain atau lebih menurut Doktrin pengertian perjanjian adalah suatu persetujuan dengan mana dua orang atau lebih saling mengikatkan diri untuk melaksanakan suatu hal dalam lapangan hukum kekayaan

Terjadinya jual beli tanah yang dilakukan oleh para pihak yaitu pihak penjual dan pihak pembeli yang akan menimbulkan perjanjian pengikatan jual beli yang dilakukan dihadapan pejabat PPAT. Perjanjian Pengikatan Jual Beli adalah suatu perjanjian yang dibuat oleh calon penjual dan calon pembeli suatu tanah/ bangunan sebagai pengikatan awal sebelum para pihak membuat Akta Jual Beli (AJB) di hadapan Pejabat Pembuat Akta Tanah (PPAT). Biasanya Perjanjian Pengikatan Jual Beli akan dibuat para pihak karena adanya syaratsyarat atau keadaankeadaan yang harus dilaksanakan terlebih dahulu oleh Para Pihak sebelum melakukan Akat Jual Beli di hadapan PPAT. Dengan demikian Perjanjian Pengikatan Jual Beli tidak dapat disamakan dengan Akat Jual Beli yang merupakan bukti pengalihan hak atas tanah/bangunan dari penjual kepada pembeli. Perjanjian Pengikatan Jual Beli (PPJB) yang dibuat dihadapan notaris merupakan akta.

Dalam kaitannya dengan akta otentik tersebut, Pasal 1870 KUH Perdata telah memberikan penegasan bahwa akta yang dibuat dihadapan notaris memiliki kekuatan pembuktian yang sempurna. Adapun, kutipannya sebagai berikut, Pasal 1870 KUH Perdata "Suatu akta otentik memberikan di antara para pihak beserta ahli warisahli warisnya atau orangorang yang mendapat hak dari mereka, suatu bukti yang sempurna tentang apa yang dimuat didalamnya."
Setelah adanya Perjanjian Pengikatan Jual Beli (PPJB) yang dilakukan oleh kedua pihak yaitu pihak penjual dan pembeli maka akan muncul yang namanya Pengikatan Jual Beli adalah kesepakatan antara penjual untuk menjual properti miliknya kepada pembeli yang dibuat dengan akta notaris. Pengikatan Jual Beli bisa dibuat karena alasan tertentu seperti belum lunasnya pembayaran harga jual beli dan belum dibayarkannya pajakpajak yang timbul karena jual beli. Pengikatan Jual Beli ada dua macam yaitu Pengikatan Jual Beli lunas dan Pengikatan Jual Beli tidak lunas. Pengikatan Jual Beli lunas dibuat apabila harga jual beli sudah dibayarkan lunas oleh pembeli kepada penjual tetapi belum bisa dilaksanakan Akta Jual Beli, karena antara lain pajakpajak jual beli belum dibayarkan, sertifikat masih dalam pengurusan dan lainlain. Dalam pasalpasal Pengikatan Jual Beli tersebut dicantumkan kapan Akta Jual Beli akan dilaksanakan dan persyaratannya. Di dalam Pengikatan Jual Beli lunas juga dicantumkan kuasa dari penjual kepada pembeli untuk menandatangani Akta Jual Beli, sehingga penandatanganan Akta Jual Beli tidak memerlukan kehadiran penjual. Pengikatan Jual Beli lunas umum dilakukan untuk transaksi atas objek jual beli yang berada diluar wilayah kerja notaris atau PPAT yang bersangkutan.

Berdasarkan Pengikatan Jual Beli lunas bisa dibuatkan Akta Jual Beli di hadapan PPAT di tempat lokasi objek berada. Pengikatan Jual Beli tidak lunas, dibuat apabila pembayaran harga jual beli belum lunas diterima oleh penjual. 
Di dalam pasalpasal Pengikatan Jual Beli tidak lunas sekurangkurangnya dicantumkan jumlah uang muka yang dibayarkan pada saat penandatanganan akta Pengikatan Jual Beli, cara atau termin pembayaran, kapan pelunasan dan sanksisanksi yang disepakati apabila salah satu pihak wanprestasi. Pengikatan Jual Beli tidak lunas juga harus ditindaklanjuti dengan Akta Jual Beli pada saat pelunasan.

Akta Jual Beli adalah akta otentik yang dibuat oleh PPAT untuk peralihan hak atas tanah dan bangunan. Pembuatan Akta Jual Beli sudah diatur sedemikian rupa melalui Peraturan Kepala Badan Pertanahan Nasional Nomor 08 Tahun 2012 Tentang Pendaftaran Tanah, sehingga PPAT tinggal mengikuti formatformat baku yang sudah disediakan. Pembuatan Akta Jual Beli dilakukan setelah seluruh pajakpajak yang timbul karena jual beli sudah dibayarkan oleh para pihak sesuai dengan kewajibannya masingmasing.

Sebelum pembuatan Akta Jual Beli, PPAT akan melakukan pemeriksaan mengenai keaslian sertifikat ke kantor Pertanahan. Penjual harus membayar pajak penghasilan $(\mathrm{PPh})$, sedangkan pembeli diharuskan membayar Bea Perolehan Hak atas Tanah dan Bangunan (BPHTB), dengan ketentuan sebagai berikut:

1. Pajak Penjual $(\mathrm{PPh}=\mathrm{NJOP} / \mathrm{Harga}$ Jual x $5 \%$ )

Pajak Pembeli (BPHTB) = $\{$ NJOP/Harga Jual - Nilai Tidak Kena Pajak\} x $5 \%$ NJOP adalah singkatan dari Nilai Jual Objek Pajak, yakni harga ratarata yang diperoleh dari transaksi jual beli yang terjadi secara wajar.

2. Calon pembeli dapat membuat surat pernyataan bahwa dengan membeli tanah tersebut maka tidak lantas menjadi pemegang Hak Atas Tanah yang melebihi ketentuan batas luas maksimum.

3. PPh maupun BPHTB dapat dibayarkan di Bank atau Kantor Pos. Sebelum PPh dan BPHTB dilunasi maka akta belum dapat dibayarkan. Biasanya untuk mengurus pembayaran PPh dan BPHTB dibantu oleh PPAT bersangkutan.

Dalam hal proses jual beli yang dilakukan oleh para pihak yaitu penjual dan pembeli tentang harga barang yang disepakati maka sesuai dengan ketentuan oleh Undang-Undang akan dikenai pajak penjualan apabila harga barang tersebut adalah Rp.60.000.000,00 (Enam puluh juta rupiah) keatas sedangkan yang dibawah harga tersebut tidak dikenakan pajak. Hal ini diatur pada UU 28/2009 tentang Pajak Daerah Dan Restribusi Daerah.

Pada Pasal 4 ayat (2) UU PPh huruf $g$ tentang yang termasuk keuntungan karena penjualan atau karena pengalihan harta salah satunya adalah: "Penghasilan dari transaksi pengalihan harta berupa tanah dan/atau bangunan, usaha jasa kontruksi, usaha real estate, dan persewaan tanahan dan/atau bangunan". Ketentuanketentuan sebagaimana disebutkan diatas, secara jelas menyebutkan bahwa pengalihan yang terjadi karena adanya jual beli dikenakan pajak penghasilan. Hal ini dikarenakan penjual dan pembeli samasama mendapatkan penghasilan atau pun keuntungan dari peralihan hak atas tanah yang dilakukannya tersebut.

Sesuai dengan ketentuan tersebut diatas pada dasarnya akta jual beli yang diterbitkan oleh PPAT adalah sah meskipun pajak PPh yang Bea Perolehan Hak Atas Tanah dan Bangunan belum terbayarkan. Hal ini disebabkan karena pada proses terjadinya jual beli terdapat perjanjian pengikatan jual beli dan pengikatan jual beli yang mana dalam 
suatu perjanjian ataupun pengikatan sudah disepakati oleh kedua belah pihak yang dalam hal ini adalah pihak penjual dan pembeli. Ini sesuai dengan ketentuan yang terdapat pada Pasal 1458 KUHPerdata disebutkan bahwa "Jual beli itu dianggap telah terjadi antara kedua belah pihak, seketika setelahnya orangorang ini mencapai sepakat tentang kebendaan tersebut dan harganya, meskipun kebendaan itu belum diserahkan, maupun harganya belum dibayar".

Berdasarkan hal tersebut maka Akta Jual Beli Tanah yang diterbitkan oleh PPAT tersebut adalah sah. Akta Jual Beli tersebut hanya tertunda penerbitannya yang disebabkan belum terbayarkannya pajak $\mathrm{PPH}$ yang Bea Perolehan Hak Atas Tanah dan Bangunan.

Jika Akta Jual Beli Tanah sudah di terbitkan oleh PPAT (Pejabat Pembuat Akta Tanah), dan Pajak PPH/BPHTB belum di bayarkan atau belum diterpenuhi maka Akta Jual Beli tersebut di katakana sah atau absah. Keabsahan Jual Beli tersebut berdasarkan pada Pasal 1458 KUHPerdata.

Apabila wajib pajak tidak melunasi utang pajak, maka dalam jangka waktu lima tahun sesudah saat terutang pajaknya, Direktur Jendral Pajak dapat menerbitkan surat ketetapan Bea Perolehan Hak atas Tanah dan Bangunan kurang bayar apabila berdasarkan hasil pemeriksaan atau keterangan lain ternyata jumlah pajak yang terutang kurang bayar. Kekurangan akan ditambah dengan sanksi administrasi berupa bunga sebesar 2\% (dua persen) sebulan untuk jangka waktu paling lama 24 (dua puluh empat) bulan, dihitung mulai saat terutangnya pajak sampai dengan diterbitkannya surat ketetapan Bea Perolehan Hak atas Tanah dan Bangunan kurang bayar.
Akibat Hukum Bagi Para Pihak Atas Pajak Jual Beli Tanah Yang Belum Terbayar

Fungsi penting aturan hukum adalah sebagai guiding behavior (penunutun perilaku). Maka setiap aturan hukum akan berdampak pada perilaku manusia. Dampak itulah yang disebut respons terhadap suatu ketentuan hukum. Respon dari suatu ketentuan tersebut berbeda tiap manusia ada yang positif dan ada yang negatif. Jadi dampak dari ketentuan hukum, bukan hanya sekadar ketaatan melainkan ada yang berupa ketidaktaatan sebab dampak merupakan efek total dari suatu ketentuan hukum.

Akibat/dampak hukum ialah akibat suatu tindakan yang dilakukan untuk memperoleh suatu akibat yang dikehendaki oleh pelaku dan yang diatur oleh hukum. Tindakan ini dinamakan tindakan hukum. Jadi dengan lain perkataan, akibat hukum adalah akibat dari suatu tindakan hukum. Contohnya adalah membuat wasiat, pernyataan berhenti menyewa, dan lain sebagainya.

Ujud dari akibat hukum menurut akibat/dampak hukum adalah akibat yang di timbulkan oleh suatu peristiwa hukum. Akibat hukum ini dapat berujud : ${ }^{4}$

1. Lahirnya, berubahnya atau lenyapnya suatu keadaan hukum

2. Lahirnya, berubahnya atau lenyapnya suatu hubungan hukum, Antara dua atau lebih subjek hukum, dimana hak dan kewajiban pihak yang satu berhadapan dengan hak dan kewajiban pihak yang lain.

3. Lahirnya sanksi apabila dilakukan tindakan yang melawan hukum.

Sebelum melakukan proses jual beli, penjual maupun pembeli harus memastikan bahwa tanah tersebut tidak

4 R. Soeroso, Pengantar Ilmu Hukum, Sinar Grafika, Jakarta, 2015, hal. 295 
sedang. Setelah halhal tersebut bisa dipastikan maka segera dilakukan pembayaran pajak yang timbul dari transaksi tersebut yaitu PPh bagi penjual dan BPHTB bagi pembeli. Pajak yang lahir dari adanya transaksi tersebut menjadi kewajiban para pihak yang dipungut langsung oleh Negara.

Menurut Wirawan B. Ilyas \& Richard Burton system pemungutan pajak dapat dibagi menjadi empat macam, yaitu:

1. Official assement system adalah suatu system pungutan pajak yang memberi wewenang kepada pemungut pajak (fiskus) untuk menentukan besarnya pajak yang harus dibayar (pajak yang terutang) oleh seseorang. Dengan system ini masyarakat (Wajib Pajak) bersifat pasif dan menunggu dikeluarkannya suatu ketetapan pajak oleh fiskus. Besarnya utang pajak seseorang baru diketahui setelah adanya surat ketetapan pajak.

2. Semiself assement system adalah suatu system pemungutan pajak yang memberi wewenang pada fiskus dan Wajib Pajak untuk menentukan besarnya pajak seseorang yang terutang. Dalam system ini setiap awal tahun pajak menentukan sendiri besarnya pajak yang terutang untuk tahun berjalan yang merupakan angsuran bagi Wajib Pajak yang harus disetor sendiri. Baru kemudian pada akhir tahun pajak fiskus menentukan besarnya utang pajak yang sesungguhnya berdasarkan data yang dilaporkan oleh Wajib Pajak.

3. Self assement system adalah suatu system pemungutan pajak yang memberi wewenang penuh kepada Wajib Pajak untuk menghitung, memperhitungkan, menyetorkan, dan melporkan sendiri besarnya utang pajak. Dalam system ini Wajib Pajak yang aktif sedangkan fiskus tidak turut campur dalam penentuan besarnya pajak yang terutang seseorang, kecuali Wajib Pajak melanggar ketentuan yang berlaku.

4. Withholding system adalah suatu system pemungutan pajak yang memberi wewenang kepada pihak ketiga untuk memotong/ memungut besarnya pajak yang terutang. Pihak ketiga yang telah ditentukan tersebut selanjutnya menyetor dan melaporkannya kepada fiskus. Pada system ini, fiskus dan Wajib Pajak tidak aktif. Fiskus hanya bertugas mengawasi saja pelaksanaan pemotongan/ pemungutan yang dilakukan oleh pihak ketiga. ${ }^{5}$

Dampak hukum bagi para pihak dalam hal pajak jual beli tanah yaitu harus memenuhi ketentuan yang berlaku. Para pihak baik penjual maupun pembeli harus samasama memenuhi kewajibannya dalam pembayaran pajak jual beli tanah tersebut. Apabila para pihak membayar atau memenuhi kewajibannya, para pihak hanya hutang kepada negara dan dikenai sanksi administrasi.

\section{PENUTUP}

\section{Kesimpulan}

Para pihak dalam perbuatan jual beli tanah adalah pihak penjual dan pihak pembeli. Didalam jual beli harus adanya kesepakatan Antara pihak penjual dan pihak pembeli yang sesuai dengan ketentuan yang tercantum pada Pasal 1320 KHUPerdata. Jual beli adalah proses yang dapat menjadi bukti adanya peralihan hak yang dilakukan oleh para pihak penjual dan pembeli dihadapan PPAT secara tunai. Pembuatan akta jual

5Wirawan B. Ilyas \& Richard Burton, Hukum Pajak, Teori, Analisis dan Perkembangannya, Salemba Empat, Jakarta, 2010, hal. 67 
beli tanah dilakukan setelah kewajiban pajakpajak harus dibayarkan.

Keabsahan akta jual beli tanah dikatakan sah apabila memenuhi sayart yang tertuang dalam Pasal 1320 KUHperdata meskipun para pihak belum memnuhi kewajibannya yaitu membayar pajak PPH/BPHTB. Para pihak hanya mempunyai hutang kepada negara dan bila belum terbayarkan maka para pihak akan dikenai sanksi denda administrasi sesuai dengan ketentuan pada Pasal 14 ayat (3) UU PPh, dan juga terhambatnya proses pendaftaran tanah selanjutnya.

\section{Saran}

Diperlukan adanya suatu regulasi yang khusus mengatur keabsahan sebuah akta PPAT dalam kaitannya dengan aspekaspek perpajakan yang timbul dari perbuatan hukum yang dituangkan dalam akta PPAT tersebut dan diperlukan juga adanya regulasi yang mengatur sanksi secara tegas bagi Subjek Pajak BPHTB dan Subjek Pajak PPH agar tidak terjadi penundaan pembayaran pajak yang menjadi kewajiban bagi masingmasing subjek pajak tersebut atas pengalihan hak atas tanah dan bangunan yang telah dilakukan.

\section{Daftar Pustaka}

C.S.T. Kansil, Pengantar Hukum Perdata, Rineka Cipta, Jakarta, 2012.

P.J.A.Adriani, Pengantar Ilmu Hukum Pajak, Cet. 3, Eresco, Bandung, 1987.

R. Soeroso, Pengantar Ilmu Hukum, Sinar Grafika, Jakarta, 2015.

Soejono Soekamto, Hukum Adat Indonesia, Raja Grapindo Persada, Jakarta, 2007.

Wirawan B. Ilyas \& Richard Burton, Hukum Pajak, Teori, Analisis dan Perkembangannya, Salemba Empat, Jakarta, 2010. 